\title{
Evaluation of the antimicrobial activity of each component in Grossman's sealer
}

\section{Avaliação da atividade antimicrobiana de cada um dos componentes do cimento de Grossman}

\author{
Ricardo Novak Savioli* \\ Jesus Djalma Pecora** \\ Henis Mian*** \\ Izabel Yoko Ito****
}

\begin{abstract}
The antimicrobial activity of Grossman's sealer and its components was evaluated on 13 different strains using the double layer well-diffusion method. Results revealed that Grossman's sealer presented antimicrobial activity against all the tested strains. Among the components of the cement, sodium tetraborate presented the greatest antimicrobial activity, both in type and diameter of the halo and ring of inhibition. Sealer powder, rosin, and eugenol presented similar activity, with no effect on P. aeruginosa and C. albicans. Among these, only eugenol had an effect on E. coli. Zinc oxide was only active against $S$. sobrinus and $E$. coli. Barium sulfate and bismuth subcarbonate did not show any antimicrobial effect.
\end{abstract}

DESCRIPTORS: Microbiology; Root canal filling materials.

\begin{abstract}
RESUMO: Os autores estudaram a atividade antimicrobiana do cimento de Grossman e de seus componentes sobre 13 diferentes cepas pelo método de difusão de poço em camada dupla. Os resultados revelaram que o cimento de Grossman apresentou atividade antimicrobiana contra todas as cepas utilizadas. Dos componentes do cimento, o tetraborato de sódio foi o que apresentou maior atividade antimicrobiana, tanto por tipo como por tamanho do halo e aro de inibição. O pó do cimento, o breu e o eugenol apresentaram atividades semelhantes, sendo que eles não tiveram ação sobre $P$. aeruginosa e $C$. albicans e, dos três componentes, somente o eugenol teve ação sobre $E$ coli. O óxido de zinco somente teve ação sobre $S$. sobrinus e E. coli. O sulfato de bário e o subcarbonato de bismuto não tiveram nenhuma ação antimicrobiana.
\end{abstract}

DESCRITORES: Microbiologia; Materiais restauradores do canal radicular.

\section{INTRODUCTION}

The aim of the root canal obturation is to replace the extirpated pulp with an inert material capable of hermetically closing the canal in order to prevent subsequent infection through the crown or through the bloodstream.

Studies by Okurama ${ }^{11}$ (1927) and Leonardo ${ }^{7}$ (2005) had already demonstrated the complexity of the internal anatomy of the root and its ramifications, making it very difficult to clean the canal. According to Peters et al. ${ }^{12}$ (1995) and Baumgartner, Falker ${ }^{1}$ (1991), instrumentation and irrigation of the root canal with disinfectants do not promote total disinfection of the canal.
The most common reason for failure in root canal therapy is related to problems in the chemo-mechanical preparation. However, bacteria resistant to therapy of good quality may occasionally be involved ${ }^{16}$.

The disinfection of the root canal system can be accomplished by the mechanical action of endodontic instruments aided by irrigant solution and intracanal medication ${ }^{14}$.

After disinfection, the canal is sealed with a root filling, and one of its main properties is to have antimicrobial activity, with the potential to eliminate residual microorganisms ${ }^{15}$. Besides that, it should also help prevent recurrent root canal

\footnotetext{
* PhD, Department of Restorative Dentistry, School of Dentistry of Ribeirão Preto; **Head Professor of Endodontics, Department of Restorative Dentistry, School of Dentistry of Ribeirão Preto; ***DDS, Microbiology Trainee, Department of Toxicologic and Bromatologic Clinical Analyses, School of Pharmaceutical Sciences; ${ }^{* * * * H e a d ~ P r o f e s s o r ~ o f ~ M i c r o b i o l o g y, ~ D e p a r t m e n t ~ o f ~ T o x i c o l o g i c ~ a n d ~}$ Bromatologic Clinical Analyses, School of Pharmaceutical Sciences - University of São Paulo.
} 
Savioli RN, Pecora JD, Mian H, Ito IY. Evaluation of the antimicrobial activity of each component in Grossman's sealer. Braz Oral Res 2006;20(2):127-31.

infection and aid the repair process of the apical and periapical tissues ${ }^{17}$.

Hence, there is scientific evidence that the antimicrobial effect of materials used in root canal obturation could compensate for possible imperfections during the phase of cleansing and disinfecting of the canal, thus cooperating with the success of endodontic treatment ${ }^{8}$.

Based on those studies, the purpose of the present study was to evaluate the antimicrobial action of Grossman's sealer and its components.

\section{MATERIALS AND METHODS}

The chemical substances used in the present study, as well as their origin, are listed in Table 1.

The sealer powder was mixed according to Grossman ${ }^{4}$ (1974) in the Laboratory of Endodontic Research, University of São Paulo.

Evaluation of the antimicrobial activity was performed through the method of well diffusion in double layer. For qualitative analyses (antimicrobial activity), this method is very reliable, swift, simple and well accepted in the literature.

The strains used as indicators for antimicrobial activity, their origins, morph types, culture media employed for obtaining of cultures and their testing are presented in Table 2.

Most canal infections appear to be multibacterial. At the present time a number of investigators have been or are attempting to define the role of specific microorganisms or groups of bacteria in the pathogenesis of pulpal and periradicular lesions. Cohen, Burns ${ }^{2}$ (1994) describe the microorganisms present in the canal. According to the authors, early studies generally reported a predominance of a facultative organism over obligatory anaerobic species. Streptococcus (alpha and gama) species, gram negative cocci and lactobacilli were most often recovered.

A study on endodontically treated teeth requiring re-treatment has shown a prevalence of facultative bacteria, especially Streptococcus faecalis instead of strict anaerobes ${ }^{5}$. The choice of

TABLE 1 - Chemical substances utilized.

\begin{tabular}{l|c|c|c}
\hline \hline \multicolumn{1}{c|}{ Material } & $\begin{array}{c}\text { Degree of } \\
\text { pureness }\end{array}$ & Brand & Origin \\
\hline $\begin{array}{l}\text { PA Zinc } \\
\text { Oxide }\end{array}$ & $99.99 \%$ & Reagen & $\begin{array}{c}\mathrm{SP}, \\
\text { Brazil }\end{array}$ \\
\hline $\begin{array}{l}\text { Sodium } \\
\text { Tetraborate }\end{array}$ & $99.50 \%$ & Vetec & $\begin{array}{c}\mathrm{SP}, \\
\text { Brazil }\end{array}$ \\
\hline $\begin{array}{l}\text { Bismuth } \\
\text { Subcarbonate }\end{array}$ & $99.90 \%$ & Reagen & $\begin{array}{c}\mathrm{SP}, \\
\text { Brazil }\end{array}$ \\
\hline $\begin{array}{l}\text { Barium } \\
\text { Sulfate }\end{array}$ & $99.90 \%$ & Carlo Erba & $\begin{array}{c}\mathrm{SP}, \\
\text { Brazil }\end{array}$ \\
\hline $\begin{array}{l}\text { Grade X } \\
\text { Rosin }\end{array}$ & & Eucatex & $\begin{array}{c}\mathrm{SP}, \\
\text { Brazil }\end{array}$ \\
\hline $\begin{array}{l}\text { Sealer } \\
\text { powder }\end{array}$ & & $\begin{array}{c}\text { Mix in accord with } \\
\text { Grossman }{ }^{4}(1974)\end{array}$ & $\begin{array}{c}\mathrm{SP}, \\
\text { Brazil }\end{array}$ \\
\hline \begin{tabular}{l} 
Eugenol \\
\hline \hline
\end{tabular} & Dierberger & $\begin{array}{c}\mathrm{SP}, \\
\text { Brazil }\end{array}$ \\
\hline
\end{tabular}

TABLE 2 - Microorganisms used as markers of activity, their origin, characteristics and culture media used for inoculation and testing.

\begin{tabular}{|c|c|c|c|c|}
\hline Microorganism & Origin & Characteristics & Media & Test \\
\hline Streptococcus mutans (1) & Saliva1 & Gram + coccus & $\mathrm{MHb}$ & $\mathrm{MHa}$ \\
\hline Streptococcus sobrinus (2) & Saliva 1 & Gram + coccus & $\mathrm{MHb}$ & $\mathrm{MHa}$ \\
\hline Streptococcus mutans (3) & Saliva 2 & Gram + coccus & $\mathrm{MHb}$ & $\mathrm{MHa}$ \\
\hline Enterococcus faecalis (4) & ATCC 10541 & Gram + coccus & $\mathrm{BHI}$ & $\mathrm{BHIa}$ \\
\hline Streptococcus sanguis (5) & Saliva & Gram + coccus & $\mathrm{MHb}$ & $\mathrm{MHa}$ \\
\hline Micrococcus luteus (6) & ATCC 9341 & Gram + coccus & $\mathrm{MHb}$ & $\mathrm{MHa}$ \\
\hline Staphylococcus aureus (7) & ATCC 25923 & Gram + coccus & $\mathrm{MHb}$ & $\mathrm{MHa}$ \\
\hline Staphylococcus aureus (8) & Pnase + Saliva & Gram + coccus & $\mathrm{MHb}$ & $\mathrm{MHa}$ \\
\hline Escherichia coli (9) & ATCC 25922 & Gram - bacillus & $\mathrm{BHI}$ & BHIa \\
\hline Escherichia coli (10) & Saliva 1 & Gram - bacillus & $\mathrm{BHI}$ & BHIa \\
\hline Pseudomonas aeruginosa (11) & ATCC 27893 & Gram - bacillus & $\mathrm{BHI}$ & BHIa \\
\hline Candida albicans (12) & ATCC 1023 & yeast & $\mathrm{MHb}$ & $\mathrm{MHa}$ \\
\hline Candida albicans (13) & Radiation-induced caries & yeast & $\mathrm{MHb}$ & $\mathrm{MHa}$ \\
\hline
\end{tabular}

$\mathrm{MHb}=$ Mueller-Hinton broth; BHI = Brain Heart Infusion; MHa = Mueller-Hinton agar; BHIa = Brain Heart Infusion agar. 
Savioli RN, Pecora JD, Mian H, Ito IY. Evaluation of the antimicrobial activity of each component in Grossman's sealer. Braz Oral Res 2006;20(2):127-31.

the microorganisms used for the present testing is based on this report.

Strains were obtained from the American Type Culture Collection (ATCC) or isolated in the Microbiology laboratory, School of Pharmaceutical Sciences, University of São Paulo.

Cultures were obtained through the introduction of marker strains into MHB medium (Mueller Hinton Broth - Difco, SP, Brazil) or BHI medium (Brain Heart Infusion - Difco, SP, Brazil), according to the physiological characteristics of each organism, and incubated at $37^{\circ} \mathrm{C}$ for 24 hours.

Testing was performed three times for each sample, using the well-diffusion in double layer method (a base layer and a seed layer composed by adequate media). The base layer consisted of $10 \mathrm{ml}$ of sterile culture medium, cooled to a temperature of about $50^{\circ} \mathrm{C}$, and then placed in sterile $20 \times 100 \mathrm{~mm}$ Petri dishes. The seed layer was obtained by plating $10^{6} \mathrm{CFU} / \mathrm{ml}$ microorganisms in culture medium cooled to around $50^{\circ} \mathrm{C}$, on top of the base layer.

Following solidification of the seed layer, wells were made by removing small portions of agar, using plastic sticks with a diameter of $4 \mathrm{~mm}$. Wells were placed at approximately $15 \mathrm{~mm}$ from the edge of the Petri dishes, at equidistant points.

Grossman's sealer was manipulated following the manufacturer's recommendations in the Laboratory of Endodontic Research, School of Dentistry, University of São Paulo, and each of its components was individually tested, by filling each well with a sufficient amount of each component. The powder/liquid ratio was set according to Savioli ${ }^{13}$ (1992). DMSO (Dimethyl Sulfoxide solvent, Merk, São Paulo, Brazil) was added to the rosin and to the whole cement powder in order to assure better diffusion due to the physical characteristics of both. DMSO was tested in order to verify whether its presence could influence the antimicrobial properties of these components.

The sealer was also tested for its activity against the plated microorganisms, 24 hours after manipulation. With this purpose, following spatulation, the cement was set into an acrylic mold specially prepared for obtaining sample units of the same size as the wells. These samples were then placed into Petri dishes plated with the different microorganisms.

Petri dishes were kept at room temperature for two hours in order to allow pre-diffusion of the material, and then incubated at $37^{\circ} \mathrm{C}$ for 24 hours.
The inhibition area formed around the well was then measured at the point of greatest width using a millimetric ruler.

\section{RESULTS}

Table 3 shows the average values, in millimeters, of the inhibition halo and ring diameters obtained through the well-diffusion method. This refers to the antimicrobial activity of each one of the components of Grossman's sealer, as well as the whole prepared cement, when put in contact with the selected microorganisms.

\section{DISCUSSION}

Because of the complexity of root canals, perfectly cleaning and shaping them with the presently available instruments is almost impossible ${ }^{2}$. Residual microorganisms left in the root canal system following cleaning and shaping or microbial contamination of a root canal system between appointments have been a concern. If the root canal treatment is completed in a single appointment, antimicrobial agents in the sealer are recommended for intracanal antisepsis ${ }^{5}$.

According to Fischer ${ }^{3}$ (1977), Mickel, Wright ${ }^{10}$ (1999) and Lai et al. ${ }^{6}$ (2001), eugenol presents proven antimicrobial activity. In the present study, it presented excellent bactericide action, since eugenol, along with sodium tetraborate, promoted inhibition halos on all of the microorganisms tested (Table 3). These results are in agreement with the chemical characteristics of this element: according to the Merck Index ${ }^{9}$, sodium tetraborate has antiseptic properties.

Barium sulfate and bismuth subcarbonate, which in the Grossman's sealer composition act as radiopaque agents, did not present antimicrobial activity.

Rosin showed a slight bactericide activity on some of the microorganisms evaluated, probably due to its slightly acidic $\mathrm{pH}$. Being rosin a plantderived resinous substance, it was not expected to present any antimicrobial activity.

Zinc oxide presented inhibition halos on some Streptococcus and Escherichia coli, and traces of inhibition on Staphylococcus aureus, showing poor antimicrobial activity. This is not in accord with Mickel, Wright ${ }^{10}$ (1999), which described zinc oxide as an antiseptic agent. These results are in agreement with the chemical characteristics of this ele- 


\begin{tabular}{|c|c|c|c|c|c|c|c|c|c|c|c|c|c|c|}
\hline \multirow{2}{*}{ 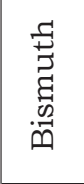 } & $\stackrel{\infty}{:}$ & 0 & 0 & 0 & 0 & 0 & 0 & 0 & 0 & 0 & 0 & 0 & 0 & 0 \\
\hline & 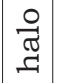 & 0 & 0 & 0 & 0 & 0 & 0 & 0 & 0 & 0 & 0 & 0 & 0 & 0 \\
\hline \multirow{2}{*}{$\begin{array}{l}\stackrel{0}{\pi} \\
\stackrel{0}{0} \\
\emptyset\end{array}$} & 离 & $\begin{array}{l}0 \\
\infty\end{array}$ & $\stackrel{n}{\wedge}$ & $\stackrel{\circ}{\Lambda}$ & 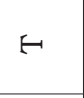 & $\stackrel{\sim \rho}{\mu}$ & $\begin{array}{l}\stackrel{1}{0} \\
0\end{array}$ & $\stackrel{0}{0}$ & $\stackrel{\circ}{\circ}$ & $\stackrel{10}{M}$ & $\stackrel{\stackrel{\sim}{\sim}}{i}$ & $\stackrel{\circ}{\circ}$ & $\stackrel{10}{\oplus}$ & $\stackrel{\stackrel{\rho}{\sigma}}{+}$ \\
\hline & 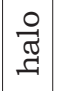 & $\begin{array}{l}\circ \\
\stackrel{-}{N}\end{array}$ & 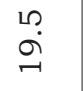 & $\begin{array}{l}\stackrel{0}{0} \\
\text { ते }\end{array}$ & 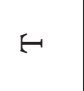 & $\stackrel{0}{\stackrel{D}{0}}$ & $\begin{array}{l}\stackrel{0}{\infty} \\
\infty \\
-1\end{array}$ & $\begin{array}{l}\circ \\
\infty \\
\rightarrow-1\end{array}$ & $\begin{array}{l}\stackrel{2}{+} \\
\sim\end{array}$ & $\begin{array}{l}\stackrel{1}{0} \\
\stackrel{M}{\rightarrow}\end{array}$ & $\stackrel{\text { ? }}{\rightrightarrows}$ & 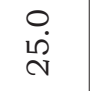 & $\begin{array}{l}\stackrel{\leftrightarrow}{\oplus} \\
\stackrel{-}{-1}\end{array}$ & $\stackrel{\circ}{\stackrel{0}{0}}$ \\
\hline \multirow{2}{*}{ 촉 } & 足 & 0 & $\stackrel{n}{i}$ & 0 & 0 & 0 & $H$ & 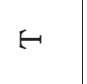 & $\mapsto$ & $H$ & $\stackrel{\circ}{-}$ & 0 & 0 & 0 \\
\hline & 足 & 0 & $\begin{array}{l}\text { ம) } \\
\text { å }\end{array}$ & 0 & 0 & 0 & 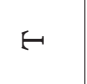 & $H$ & $\mapsto$ & $\stackrel{\circ}{\circ}$ & $\begin{array}{l}\circ \\
\circ\end{array}$ & 0 & 0 & 0 \\
\hline \multirow{2}{*}{ 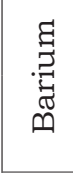 } & 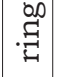 & 0 & 0 & 0 & 0 & 0 & 0 & 0 & 0 & 0 & 0 & 0 & 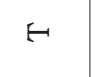 & 0 \\
\hline & 疍 & 0 & 0 & 0 & 0 & 0 & 0 & 0 & 0 & 0 & 0 & 0 & $H$ & 0 \\
\hline \multirow{2}{*}{$\begin{array}{l}\overrightarrow{0} \\
\vec{d} \\
\text { D. } \\
\underset{J}{J} \\
\text { | }\end{array}$} & 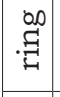 & $\stackrel{\text { ?ִ }}{\wedge}$ & $\stackrel{\circ}{\circ}$ & $\stackrel{\circ}{\circ}$ & $\stackrel{\circ}{\circ}$ & $\stackrel{n}{\infty}$ & $\stackrel{\circ}{\dot{m}}$ & $\stackrel{\circ}{i}$ & $\stackrel{\circ}{i}$ & 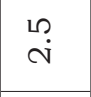 & $\stackrel{\sim}{\sim}$ & $H$ & $H$ & $\mapsto$ \\
\hline & 옴 & $\begin{array}{l}0 \\
\dot{0}\end{array}$ & $\begin{array}{l}0 \\
\dot{\theta}\end{array}$ & $\begin{array}{l}0 \\
\stackrel{1}{n}\end{array}$ & $\stackrel{\circ}{\circ}$ & $\stackrel{\circ}{\stackrel{+}{-}}$ & $\stackrel{0}{\dot{m}}$ & $\stackrel{\circ}{\stackrel{\longrightarrow}{\rightleftarrows}}$ & $\begin{array}{l}0 \\
0\end{array}$ & $\begin{array}{l}\stackrel{2}{\sim} \\
\stackrel{\sim}{\sim}\end{array}$ & $\begin{array}{l}\stackrel{\circ}{\dot{T}} \\
\stackrel{\sim}{\sim}\end{array}$ & $H$ & $H$ & 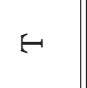 \\
\hline \multirow{2}{*}{ 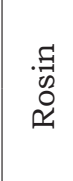 } & 疽 & $\stackrel{\circ}{+}$ & $\stackrel{\circ}{\dot{\sigma}}$ & $\ddot{n}$ & $H$ & $\stackrel{n}{\infty}$ & $\stackrel{0}{0}$ & $\stackrel{\circ}{i}$ & I? & 0 & 0 & 0 & 0 & 0 \\
\hline & 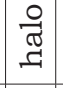 & $\begin{array}{l}\stackrel{n}{0} \\
\stackrel{\oplus}{\rightarrow}\end{array}$ & $\stackrel{\stackrel{n}{ }}{\stackrel{M}{\rightarrow}}$ & $\stackrel{\stackrel{\rho}{0}}{\stackrel{\oplus}{\rightarrow}}$ & $\stackrel{\circ}{\stackrel{-}{\beth}}$ & $\stackrel{\circ}{\stackrel{\dot{m}}{\sim}}$ & $\stackrel{\circ}{\stackrel{\circ}{二}}$ & $\stackrel{\circ}{\stackrel{\longrightarrow}{\rightleftarrows}}$ & $\stackrel{10}{0}$ & 0 & 0 & 0 & 0 & 0 \\
\hline \multirow{2}{*}{$\begin{array}{ll}0 & \overrightarrow{0} \\
0 & 0 \\
0 & 0 \\
3 & 0 \\
3 & 0\end{array}$} & 贯 & $\stackrel{\circ}{\circ}$ & $\stackrel{\circ}{\circ}$ & $\stackrel{\circ}{\circ}$ & $H$ & $\stackrel{\circ}{+}$ & ம) & $\stackrel{0}{m}$ & $\stackrel{\circ}{i}$ & $\stackrel{\circ}{-}$ & 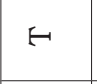 & 0 & 0 & 0 \\
\hline & 옳 & $\begin{array}{l}\text { L } \\
\text { in } \\
\sim\end{array}$ & $\stackrel{\stackrel{L}{+}}{\underset{\sim}{-}}$ & $\begin{array}{l}10 \\
\stackrel{0}{0} \\
-1\end{array}$ & $H$ & $\stackrel{\mathscr{L}}{\stackrel{\oplus}{\rightarrow}}$ & $\begin{array}{l}\circ \\
\stackrel{\leftrightarrow}{0}\end{array}$ & $\stackrel{\circ}{\stackrel{m}{-}}$ & $\begin{array}{l}\circ \\
-\end{array}$ & $\stackrel{0}{\circ}$ & 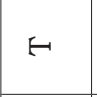 & 0 & 0 & 0 \\
\hline \multirow{2}{*}{ 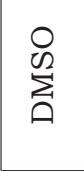 } & 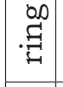 & 0 & 0 & 0 & 0 & 0 & 0 & 0 & 0 & 0 & 0 & 0 & 0 & 0 \\
\hline & 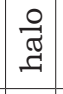 & 0 & 0 & 0 & 0 & 0 & 0 & 0 & 0 & 0 & 0 & 0 & 0 & 0 \\
\hline \multirow{2}{*}{ 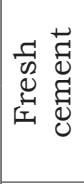 } & 告 & $\begin{array}{l}\text { ம) } \\
\text { in }\end{array}$ & $\stackrel{\circ}{\circ}$ & $\stackrel{\circ}{\circ}$ & $\stackrel{n}{i}$ & $\begin{array}{l}\llcorner 0 \\
0\end{array}$ & $\begin{array}{l}0 \\
\text { in }\end{array}$ & $\stackrel{\llcorner}{\mathscr{r}}$ & $\stackrel{n}{\infty}$ & $\stackrel{\circ}{\circ}$ & $\stackrel{\circ}{\circ}$ & $\stackrel{\circ}{\stackrel{\leftrightarrow}{c}}$ & $\stackrel{\sim}{\sim}$ & $\stackrel{n}{m}$ \\
\hline & 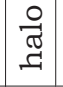 & $\stackrel{0}{\stackrel{1}{\circ}}$ & $\begin{array}{l}\stackrel{1}{0} \\
\stackrel{\leftrightarrow}{0}\end{array}$ & $\stackrel{\circ}{\stackrel{\circ}{-}}$ & 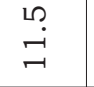 & $\stackrel{0}{\dot{\varphi}}$ & 오․ & $\begin{array}{l}0 \\
\stackrel{D}{D}\end{array}$ & $\stackrel{10}{\stackrel{2}{\sim}}$ & $\begin{array}{l}\stackrel{2}{0} \\
\stackrel{M}{-}\end{array}$ & $\stackrel{\sim}{\stackrel{n}{n}}$ & $\begin{array}{l}\stackrel{\bigcirc}{\sim} \\
\stackrel{\sim}{-}\end{array}$ & $\begin{array}{l}\stackrel{2}{0} \\
\stackrel{\sim}{\sim}\end{array}$ & $\stackrel{\circ}{\underset{+}{-}}$ \\
\hline \multirow{2}{*}{ 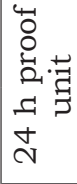 } & . & $\stackrel{0}{0}$ & $\stackrel{\circ}{\wedge}$ & $\stackrel{\circ}{r}$ & $\stackrel{\circ}{\dot{m}}$ & $\stackrel{\circ}{\circ}$ & $\stackrel{0}{\circ}$ & $\stackrel{\circ}{\wedge}$ & $\stackrel{0}{0}$ & $\stackrel{\circ}{\wedge}$ & $\stackrel{\circ}{\infty}$ & $H$ & $\begin{array}{l}\circ \\
\dot{M}\end{array}$ & $\begin{array}{l}0 \\
\text { in }\end{array}$ \\
\hline & 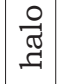 & $\begin{array}{l}0 \\
\infty \\
\sim\end{array}$ & $\begin{array}{l}0 \\
\dot{i}\end{array}$ & $\stackrel{0}{\dot{0}}$ & 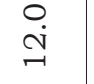 & $\begin{array}{l}\stackrel{\circ}{\dot{d}} \\
\stackrel{\sim}{N}\end{array}$ & 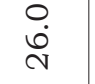 & $\stackrel{0}{\circ}$ & $\stackrel{\circ}{0}$ & 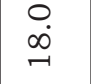 & $\stackrel{0}{\dot{0}}$ & $\stackrel{* k}{F}$ & $\begin{array}{l}\stackrel{0}{\sim} \\
\stackrel{\sim}{\sim}\end{array}$ & $\stackrel{0}{\dot{\theta}}$ \\
\hline 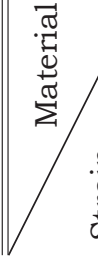 & స్స్ & 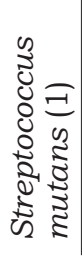 & 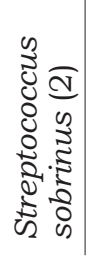 & 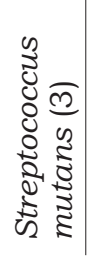 & 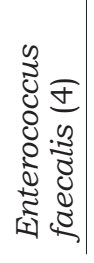 & 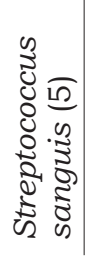 & 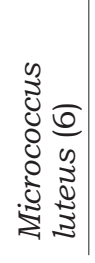 & 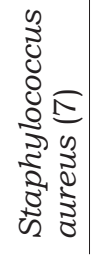 & 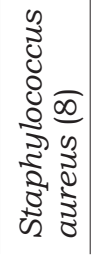 & 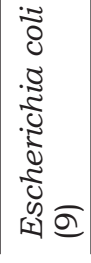 & 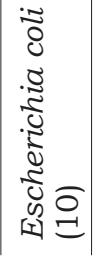 & 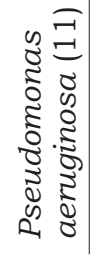 & 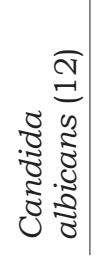 & 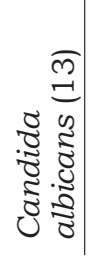 \\
\hline
\end{tabular}


ment. Zinc oxide is antiseptic, astringent and has protective properties ${ }^{9}$.

Grossman's sealer powder presented antimicrobial activity against almost all the strains used in the present study, except for Pseudomonas aeruginosa and Candida albicans. The prepared cement, both fresh and already set, also displayed antimicrobial activity against all strains used. This was due to the antimicrobial activity of some of its components, mainly sodium tetraborate and eugenol, which combined, led to positive results. These results are in agreement with those of Mickel, Wright ${ }^{10}$ (1999). According to the authors, the zinc oxide-eugenol sealer was found to be more effective in inhibiting the growth of Streptococcus anginosus than three of the calcium hydroxidecontaining sealers.

\section{REFERENCES}

1. Baumgartner J, Falker W. Bacteria in the apical infected root canal. J Endod 1991;17:380-4.

2. Cohen S, Burns RC. Pathways of the pulp. $6^{\text {rd }}$ ed. Missouri: Mosby; 1994.

3. Fischer FJ. The effect of three proprietary lining materials on microorganisms in carious dentine. An in vitro investigation. Br Dent J 1977;43:231-5.

4. Grossman LI. Endodontic pratice. $8^{\text {th }}$ ed. Philadelphia: Lea \& Febiger; 1974.

5. Ingle JI, Bakland IK. Endodontics. $5^{\text {th }}$ ed. Hamilton: Bc Decker Inc; 2002.

6. Lai CC, Huang FM, Yang HW, Chan Y, Huang MS, Chou MY, et al. Antimicrobial activity of four root canal sealers against endodontic pathogens. Clin Oral Investig 2001;5:236-9.

7. Leonardo MR. Endodontia - tratamento dos canais radiculares. São Paulo: Artes Médicas; 2005.

8. Lin LM, Skribner JE, Gaengler P. Factors associated with endodontic treatment failures. J Endod 1992;18:625-7.

9. Merck \& Co. Inc. Merck Index: an encyclopedia of chemicals, drugs, and biologicals. 10 $0^{\text {th }}$ ed. Rahway: Merck; 1983.

10. Mickel AK, Wright ER. Growth inhibition of Streptococcus anginosus (milleri) by three calcium hydroxide sealers and one zinc oxide-eugenol sealer. J Endod 1999;25:34-7.

\section{CONCLUSIONS}

Based on the methodology applied and on the results obtained, it could be concluded that:

1. Grossman's sealer displayed antimicrobial activity against all strains used.

2. Among the components of the cement, sodium tetraborate presented the greatest antimicrobial activity, both in type and dimensions of the inhibition halos and rings.

3. Cement powder, rosin, and eugenol presented similar activity, with no effect against $P$. aeruginosa and C. albicans. Among the three of them, only eugenol presented activity against $E$. coli.

4. Zinc oxide was active only against $S$. sobrinus and E. coli.

5. Barium sulfate and bismuth subcarbonate did not present any antimicrobial activity.

11. Okurama T. Anatomy of root canals. J Am Dent Assoc 1927;14:632-7.

12. Peters LB, Wesselink PR, Moorer WR. The fate and the role of bacteria left in root dentinal tubules. Int Endod J 1995;28:95-9.

13. Savioli RN. Efeito da influência de cada componente químico do cimento de Grossman sobre suas propriedades físicas [Dissertação de Mestrado]. Ribeirão Preto: Faculdade de Odontologia de Ribeirão Preto da Universidade de São Paulo; 1992.

14. Siqueira JF Jr, Batista MM, Fraga RC, de Uzeda M. Antibacterial effects of endodontic irrigants on black pigmented gram negative anaerobes and facultative bacteria. J Endod 1998;24:414-6.

15. Siqueira JF, Favieri A, Gahyva SMM, Moraes SR, Lima KC, Lopes HP. Antimicrobial activity and flow rate of newer and established root canal sealers. J Endod 2000;26:274-7.

16. Siren EK, Haapasalo MPP, Ranta K, Salmi P, Kerosuo ENJ. Microbiological findings and clinical procedures in endodontic cases selected for microbiological investigation. Int Endod J 1997;30:91-5.

17. Tronstad L, Andreasen JO, Hasselgren G, Kriterson L, Riis I. pH changes in dental tissue after root canal filling with calcium hydroxide. J Endod 1988;14:125-7. 